\title{
FOREIGN LANGUAGE LISTENING SKILLS FORMATION OF FUTURE IT SPECIALISTS USING INTERNET RESOURCES
}

Summary. The article considers the foreign language listening skills formation of future IT specialists in higher educational institutions. Perception of audio messages requires hard work of mental and intellectual processes that need to be developed and improved in the learning process. Peculiarities of listening as one of the types of speech activity are considered. Its influence on the development of listeners' communication skills is shown. This type of activity teaches students to listen carefully to the language spoken, forms the ability to predict the semantic content of the text and cultivates a culture of listening not only foreign but also native language. Listening is considered as an action that is part of communicative activities and is used in oral communication, which is subject to social needs. However, absence of authentic foreign language environment, lack of repeated and systematic listening practice, low motivation, psychological barriers are the obstacles on the way to developing proficiency in listening.

The article analyzes researches in listening skills formation of IT students. Linguists have long been interested in this question. Some of them emphasize the acquisition of a foreign language and the development of speaking skills is carried out mainly through listening, which causes the greatest difficulties. The main language difficulties of listening, which are faced by students of non-language technical institutions at the initial stage of study, are analyzed in the work. Special attention is paid to difficulties of listening process, the main factors influencing the formation of foreign language listening skills, as well as the possibilities of information computer technology (ICT) and Internet resources using in the educational process. The classification of special Internet resources for learning a foreign language by future IT specialists is presented. Specific examples of sites, resources, applications with a brief description of their purpose and features are given.

Key words: listening, communicative competence, communication skills, audio text, information computer technology, speech activity, IT specialists.

Problem statement. Foreign languages speaking, in particular English as the language of international communication is a priority requirement of today. Modern teaching methods of foreign languages consider communicative competence as a fundamental skill of foreign language communication. It consists of four type's formation: listening, speaking, reading and writing. The learning process focuses on the practical skills of foreign language, great importance should be given to the perception and critical understanding of a foreign language by ear. Thus, listening is one of the effective means of forming and developing of communication skills.

It should be noted the requirements of Ukrainian higher education institutions to the foreign language competence of graduates are presented in the branch standards of higher education in
Ukraine. According to the authors of standards [1-3] foreign language competence refers to the general competencies of the specialist and includes knowledge of lexical, grammatical, stylistic features of state and foreign vocabulary, terminology in computer science, grammatical structures for understanding and production orally and in writing foreign texts in the professional sphere, ability to communicate professionally in state and foreign languages, development of documentation in state and foreign languages for information technology systems, products and services, read, understand and apply technical documentation in Ukrainian and foreign languages in professional activities. Foreign language training of future IT professionals is an integral component of the branch standard. In the last 5-7 years, transformations have taken place in higher education institutions not only in the name of the disciplines with an emphasis on professional orientation, but also changes in the purposes of its study and the courses' content.

Recent researches and publications. The importance of listening skills developing in the context of the competency approach and intercultural communication is growing. In this regard, scientists study the process of listening skills formation, clarify the goals and formation stages, and search for tools that have high linguo didactic potential, develop criteria and ways to control the level of listening skills in accordance with the professional orientation of future professionals. Among the most relevant researches in listening skills formation and developing, we can highlight the following:

1) use of modern authentic audio/video materials with the help of information and communication technologies;

2) organization and intensification of independent extracurricular work with foreign language audio / video, online materials etc.;

3 ) formation of motivation and ability to autonomous listening;

4) training of professionally-oriented listening [4].

Due to the rapid development of IT and Internet technologies there are a lot of teaching methods of foreign languages, i.e. the latest models of listening teaching with authentic video and audio materials using new information technologies and Internet resource. Methods of listening teaching on the basis of podcasts (A. Solomatina [5]), interview texts (O. Zakharova [6]), TV news (L. Panova, R. Vikovich), feature films (M. Novikov), video materials (V. Pisarenko, N. Novogradskaya-Morskaya [7]), artistic audio works (V. Chernysh, O. Sivachenko [8]), radio programs of information genres (O. Kolesova), etc. have been developed. Methods of professionally-oriented listening in technical universities were developed by the following researchers V. Yakovleva, S. Timina, S. Gubareva, D. Morozov and others [4].

These studies make a contribution to solving the problem of listening teaching of future IT professionals. However, 
the issue of developing and improving listening skills using Internet resources and developing appropriate effective teaching methods is unresolved completely.

The main goal of the article is to identify and characterize the main stages of listening learning, formation and development of foreign language communication skills of future IT professionals of higher education institutions using Internet resources.

Main material. Listening is a receptive type of speech activity, which is the simultaneous perception and understanding of speech by ear. As an independent type of speech activity has its own goals, objectives, subject and result [9].

Listening is a hard work of all mental processes, perception of the received information in the form of a sound, it's processing and comparison with standards stored in the long-term memory of students, cognition and understanding of thought. Listening comprehension is a complex and multifaceted skill. It is very relevant, but causes a number of difficulties associated with the objective characteristics of this type of speech activity, and with the methods of listening training [10].

Listening is a complex speech mental activity. It is based on natural ability, which is improved in the process of individual development and allows understanding information in the acoustic code, to accumulate it in memory or writing, to select and evaluate it according to interests or tasks.

Important factors in listening skills formation are:

- perceptual and speech-forming prerequisites;

- general intellectual prerequisites;

- factual knowledge;

- knowledge and skills in the native language;

- foreign language practical skills;

- motivation.

These factors are the basis for development of specific skills and abilities. It is based on listening teaching in accordance with the European educational standard in a foreign language [11].

So, it is necessary to pay attention to the socio-cultural differences of oral speech of a foreign language, compared to the native language or other foreign languages. If such differences are not mastered, the correct understanding of the original authentic texts will be difficult [12, p. 220].

Therefore, during listening teaching in technical universities, it is necessary to use educational and authentic audio materials at the initial learning stage and authentic materials at further training. The material basis of listening is audio text. Like any text, it should have the composition, structure and semantic organization. In addition, audio material, in contrast to the written text, is characterized by intonation, a certain tempo of sound, as well as the uniqueness and irreversibility of perception. The main requirement to the content of texts for listening should be informative and interesting plot. In the practice of foreign languages teaching, it is recommended to use audio texts, available in content and language composition, short in duration and mostly monothematic [11, p. 122].

Let's consider the main stages of listening training.

1. The initial stage is the key in listening teaching. It is necessary to prepare students for perception of foreign language text, get acquainted with the topic proposed in the material, ask questions to the text or predict its content. The teacher should draw students' attention to lexical, phonetic and grammatical difficulties of the language being studied, and create a favorable psychological atmosphere.
2. Listening stage. Students should be taught not only to understand the main content of the plot, but also to extract the necessary information from it. To overcome the erroneous tendency to "listen hard", it is necessary to teach students to perceive the text mainly globally, focusing on awareness of the general content and meaning, not trying to hear every word and not paying special attention to individual words or even parts of audio text [13].

3. The final stage. The main condition is the use of exercises to understand the listened material. For example, students should determine the topic of the listened material, discuss key issues etc. It is expedient to use test tasks at the stage. Teacher should test student's ability to understand the main content of the text and skills to identify the main ideas, details, divide the text into semantic parts, establish logical connections between parts of the text, as well as distinguish speech functions, attitudes, intentions, feelings and thoughts expressed by the speaker (speakers). Researcher 0 . Kvasova in "Fundamentals of foreign language skills and abilities testing" suggests after listening to use the following tasks:

- multiple-choice tasks. Each part of the listened text is asked a question with three options, only one is correct;

- tasks for multiple comparison. There is a comparison of the listened content with the statements, figures, tables presented on paper;

- open question tasks. Students should fill in gaps in the text, tables and add or complete sentences;

- Yes/no tasks. The purpose is to test the ability to understand associations, relationships, definitions, as well as the ability to summarize the content of longer texts and understand their main content [14, p. 57-61].

Take into consideration specifics of listening as one of the most difficult types of speech activity. It is important to pay attention to the main difficulties of its learning.

Let's consider the main difficulties of listening skill formation. The first is phonetic difficulties. They are associated with insufficient development of phonemic hearing, lack of certain speech skills, and not enough formation of acoustic and articulatory images of the listener. Logical intonation is also quite difficult to hear. It divides phrases into complete semantic segments and serves to highlight the main idea and determines the communicative type of phrase, lexical emphasis, which carries the main semantic load, tempo and individual features of the speaker's pronunciation. Secondly, lexical difficulties are related to the quantitative volume of vocabulary, its thematic diversity, use of figurative words and idiomatic phrases. Third, grammar is related to syntax and morphology. Some grammatical difficulties are due to the presence of analytical forms that are absent in the native language. Grammatical homonymy causes difficulties, especially in official words.

Researches in psychology also show the simultaneous perception of language form and understanding of the content of oral expression is a very complex psychological activity. There are several factors that hinder effective listening:

- the inability of listener to perceive the information. It is associated with underdeveloped phonemic speech listening;

- comprehension of an utterance, i.e. decoding of information;

- lack of attention;

- inaccurate understanding of the text, because of unfamiliar vocabulary or language constructions [15].

Successful foreign language listening skills formation of future IT specialists aims to overcome these difficulties. 
Visual contact between the speaker and the listener can be a support for a better understanding of the audio material. Therefore, in our opinion, the educational films, feature films about computer technologies and Internet resources are appropriate in foreign language classes at listening training. It contributes to the development of motivation of students' speech activity and interest in foreign languages. One of the advantages of educational films using in listening learning is the possibility to watch them with subtitles. Thus, students have possibility to combine two types of speech activities - reading and listening and correlate what they see with what they hear, because while listening, the visual background and video are essential for them to perceive and understand audio material.

So, listening success depends on the speaker's individual characteristics - the tone of the voice, the volume of speech, tempo, regional features, as well as certain speech defects. These conditions of perception should be taken into account by the teacher. Students should have opportunity to listen to many different people with different voices and individual characteristics of speech [12]. It is easy to realize the speech watching an educational or feature film, preferably with subtitles, because in feature films there are often elements of "live" everyday speech, not inherent in literary language. At watching movies, the visual analyzer greatly facilitates the perception and understanding of speech by ear. Visual support, such as the speech organs of the characters, gestures, facial expressions, the conditions in which they are, the environment, etc. support auditory perception, facilitate internal speech, understanding of what is said and further prediction of the situation.

It should be noted the expediency of Internet resources using at listening teaching in higher education is very important. The main purpose of the World Wide Web using for speech competence formation of foreign language is to create modern learning conditions for students, interest them, encourage them to learn foreign languages, expand their knowledge and experience. Due to the urgency of the study of professional English by IT professionals, a wide variety of special Internet resources is now available. Consider the classification of Internet resources in listening skills development proposed by researcher S. Symonenko:

1) resources with podcasts in IT (herdingcode.com and se-radio.net -podcasts for software engineers on various topics, ruby5. codeschool.com and Ruby Rogues are podcasts for Ruby programmers, talkpythontome.com - for Python programmers etc.);

2) sites of online movies and series for learning English (ororo.tv - movies and series with subtitles in English and other languages; show-english.com is a site for watching movies in English with subtitles);

3) short video resources (ted.com - video service of ideas, usually in the form of short, powerful speeches; englishcentral.com 2-3 minute videos with subtitles);

4) educational video channels on video hosting (Sentdex - educational videos on YouTube for Python programmers, Cave of Programming - YouTube channel for learning programming in Java and $\mathrm{C}++$, etc.);

5) IT news (reddit.com; news.ycombinator.com; smashingmagazine.com - a professional online magazine for software developers and web designers, etc.);

6) social networks, virtual communities and virtual environments, in particular, for learning different subjects, acquiring new knowledge, communication, information retrieval, etc. [16].
Thus, the use of internet educational resources should be systemic and supported by interdisciplinary links in the training of future software engineers in higher education.

Conclusions. Listening as a type of communicative activity can be conditionally considered as a component of foreign language communication. There is a two-way exchange of information between the participants of communicative act. The foreign speech perception is facilitated by the external factors: facial expressions, gestures, body language, and other ways of expressing speaker's emotional state and attitude to the presented and received information.

On the other hand, listening is an independent type of communication. It takes form of a one-way speech flow (for example, perceiving speech on radio or television). This type of audition is undoubtedly more complex. In the absence of a real foreign language environment in future IT professionals training, listening of professionally oriented authentic texts involves the use of Internet resources for professional purposes.

Thus, the success of understanding and memorizing the information perceived by the ear by future IT professionals is determined by both objective and subjective factors. Objective factors include the conditions under which the text is provided by ear: the presence of unfamiliar grammatical phenomena, vocabulary, the pace of speech and its individual characteristics, uniqueness, shortness of perceived information.

Subjective factors are determined by the features of the psyche that perceive foreign speech by ear, and the level of formation of listening mechanisms (the presence of phonemic and speech hearing skills, auditory memory, attention, internal articulation, imagination, prognostic abilities). (Article 52) Prospects for further development of the problem under study are to develop an effective methodological system of exercises for the effective formation and development of listening skills in future IT professionals in higher education.

\section{References:}

1. Standard of higher education of Ukraine of the first (bachelor's) level of the degree "bachelor" in the field of knowledge 12 "Information technologies" specialty 122 "Computer science and information technologies". Kyiv, 2016. 25 p.

2. Standard of higher education of Ukraine of the first (bachelor's) level of the degree "bachelor" in the field of knowledge 12 "Information Technologies" specialty 121 "Software Engineering”. Kyiv, 2018. 24 p.

3. Standard of higher education of Ukraine of the first (bachelor's) level of the degree "bachelor" in the field of knowledge 12 "Information Technologies” specialty 123 “Computer Engineering”. Kyiv, 2016. 17 p.

4. Bilyanskaya, I.P. Current state of research on the problem of forming foreign language additive competence of students. Bulletin of Cherkasy University. Series "Pedagogical Sciences”. 2017. № 9. P. 69-81.

5. Solomatin, A.G. Development of speaking and listening skills of students through educational podcasts. Language and culture. 2011. № 2 (14)

6. Zakharova, O.Y. Features of teaching listening to authentic texts in senior classes of schools with in-depth training in English. Collection of scientific articles of graduate students. 3 4. Syktyvkar, 2006.

7. Novogradskaya-Morskaya, N.A. Training of future marketers of professionally oriented listening with the use of authentic Englishlanguage video materials: dissertation. K., 2014. 203 p.

8. Sivachenko, O.O. Teaching audition of English dramatic works of students of senior courses of language specialties: dissertation. K., 2009. $284 \mathrm{p}$. 
9. Kovtun, L., Arkhipenko, L., Ananyeva, N., Kolobova, T. Formation of students' skills of oral speech, reading and writing in a foreign language. Rostov, $1998.96 \mathrm{p}$.

10. Surah, N.A. Training of future ICT specialists in listening to a foreign language on the basis of authentic professional texts. Spirituality of personality: methodology, theory and practice. 11 (48). 2012. P. $157-163$.

11. Nikolaeva, S.Yu. Methods of teaching foreign languages in secondary schools: a textbook. Kyiv: Lenvit, 2002. 328 p.

12. Golotyuk, O.V. Features of listening in higher educational institutions. Pedagogical sciences. 2013. Vol. 64. P. 220-225.

13. Tarnapolsky, O.B. Methods of teaching foreign language speech activity in higher education: textbook. manual. Kyiv: INC OS Company, 2006. 248 p.

14. Kvasova, O.G. Fundamentals of testing foreign language skills and abilities: textbook. manual. Kyiv: Lenvit, 2009. 119 p.

15. Gorunova, M.M. Listening and the principle of authenticity in foreign language teaching. Development Strategy of Ukraine: Economic and Humanitarian Dimensions: International. scientific-practical conf. Kyiv: "Information and Analytical Agency", 2016. P. 358.

16. Symonenko, S.V. Formation of communicative competence of specialists in software engineering in higher education institutions: author's dissertation: Candidate of Pedagogical Sciences: 13.00.04. Kyiv, 2019. 240 p.

Гнсдкова О.О. Формування навичок аудіювання іноземної мови майбутніх IT-фахівців із використанням Інтернет-ресурсів

Анотація. У статті розглядається формування навичок аудіювання іноземної мови в майбутніх IT-фахівців у вищих навчальних закладах. Сприйняття звукових повідомлень вимагає напруженої роботи розумових та інтелектуальних процесів, які потребують розвитку та вдосконалення в навчальному процесі. Розглянуто особливості аудіювання як одного з видів мовленнєвої діяльності. Показано його вплив на розвиток комунікативних навичок слухачів. Цей вид діяльності вчить студентів уважно слухати мову, на якій розмовляють, формує вміння передбачати смисловий зміст тексту та виховує культуру сприйняття не лише іноземної, а й рідної мови. Аудіювання розглядається як дія, яка є частиною комунікативної діяльності і використовується в усному спілкуванні, що підпорядковується соціальним потребам. Однак відсутність автентичного іншомовного середовища та багаторазової та систематичної практики аудіювання, низька мотивація, психологічні бар'єри є перешкодами на шляху до розвитку навичок аудіювання. У статті проаналізовано дослідження формування навичок аудіювання студентів IT-спеціальностей ВНЗ. Мовознавці давно цікавляться цим питанням. Деякі з них наголошують на оволодінні іноземною мовою, а розвиток мовленнєвих навичок здійснюється переважно за допомогою аудіювання, що викликає найбільші труднощі. У роботі проаналізовано основні мовні труднощі аудіювання, з якими стикаються іноземні студенти технічних закладів на початковому етапі навчання. Особлива увага приділяється труднощам процесу аудіювання, основним чинникам, що впливають на формування навичок аудіювання іноземних мов, а також можливостям використання інформаційних комп'ютерних технологій (IКТ) та Інтернет-ресурсів у навчальному процесі. Представлено класифікацію спеціальних Інтернет-ресурсів для вивчення іноземної мови майбутніми IT-спеціалістами. Наводяться конкретні приклади сайтів, ресурсів, програм із коротким описом їх призначення та особливостей.

Ключові слова: аудіювання, комунікативна компетентність, комунікативні навички, аудіотекст, мовленнєва діяльність, ІТ-фахівці. 